Review article

\title{
Kuramdan Uygulamaya Kapsayıcı Eğitim: Ortaöğretim İngilizce Dersi Kapsayıcı Öğretim Programının İncelenmesi ve Öneriler
}

\section{Inclusive Education from Theory to Practice: Study of the Secondary Education English Inclusive Teaching Program}

\author{
Turan Palabıyık (D) a,* \& Halis Sakız (D) ${ }^{\mathrm{b}}$ \\ a Department of Curriculum and Instruction, Institute of Educational Sciences, Dicle University, Diyarbakır, Turkey \\ ${ }^{b}$ Department of Educational Sciences, Faculty of Education, Mardin Artuklu University, Mardin, Turkey
}

\begin{abstract}
Özet
Kapsayıcı eğitim, bireyin din, dil, ırk, cinsiyet, ekonomik ve toplumsal farklılıklarına bakılmaksınız, farklılıkların zenginlik ve eğitimin bir hak olduğu anlayışıyla, eğitime ulaşmadaki engelleri ortadan kaldırarak her bireyin eğitim olanaklarına ulaşmasını savunmaktadır. Bu nedenle hazırlanacak olan programın, öğrenci istek, tercih ve ihtiyaçlarına göre, ayrıca öğrencilerin akademik farklııkları dikkate alınarak, bireyselleştirilmiş olarak düzenlenmesi, gerektiğinde bireyin kendi programını kendisinin hazırlanması önemlidir. Ayrıca kapsayıcı eğitimin demokratik ve sosyal adalet anlayışına sahip bireyler yetiştirmede etkinliğinin ortaya çıkmasıyla, toplum, okul ve sınıf ortamında yapılması gereken düzenlemelerle ilgili, bu çalışmanın yapılması ihtiyacı ortaya çıkmaktadır. Bu çalışmanın amacını kapsayıcı eğitimin ilkeleri, temelleri, gereksinimleri ve gerekçeleri doğrultusunda, ortaöğretim İngilizce öğretim programının yeniden düzenlenmesini sağlayarak, Milli Eğitim Bakanlığının İngilizce dersi ortaöğretim programına alternatifler sunmasıdır. Çalışma, başından sonuna kadar çağımızda oldukça yaygınlaşmaya ve gereksinimi hissedilmeye başlayan kapsayııı eğitimin ilkelerini, temellerini, gereksinimlerini ve gerekçelerini merkeze alarak, uygulamada kapsayıcı eğitim anlayışını, ortaöğretim İngilizce öğretim programına kazandırmayı amaçlamaktadır.
\end{abstract}

Anahtar Kelimeler: Kapsayıcı Eğitim, Ortaöğretim İngilizce Öğretim Programı, Öğretim Programı İncelemesi.

\section{Abstract}

Inclusive education advocates that each individual should access educational opportunities by looking at the differences of religion, language, race, gender, economic and social differences of the individual, accepting differences as wealth, eliminating situations that would prevent the individual from accessing education with the understanding that education is a right.Therefore, it is important to organize the program to be prepared individually according to the student's wishes, preferences and needs, as well as taking into account the academic differences of the students, and to prepare the individual's own program when necessary.In addition, with the emergence of the effectiveness of inclusive education in raising individuals with a democratic and social justice approach, the need to carry out this study on the arrangements to be made in society, school and classroom environment arises.The aim of this study is to provide alternatives to the English course secondary education program of the Ministry of National Education by reorganizing the secondary education curriculum in line with the principles, foundations, requirements and reasons of inclusive education. The study aims to bring the concept of inclusive education in practice to the

\footnotetext{
* Corresponding author:

Turan Palabıyık, Department of Curriculum and Instruction, Institute of Educational Sciences, Dicle University, Diyarbakır, Turkey. Email: turanpalabiyik@gmail.com
} 
secondary English curriculum by centering the principles, foundations, requirements and justifications of inclusive education, which has become quite widespread and felt in our age from the beginning to the end of the study.

Keywords: Inclusive Education, Secondary English Teaching Program, Curriculum Review.

\section{Gíriș}

Kapsayıcı eğitim, eğitim programlarının öğrenci ihtiyaç, özellik ve tercihlerine uyumlu bir şekilde tasarlanmasını, uygulama süreçlerinin ise öğrencinin etkin katılımını sağlayacak şekilde gerçekleşmesini öngörmektedir (Booth \& Ainscow, 2002). Buna paralel olarak geliştirilecek eğitim programları öğrencinin ilgi, tutum ve becerisini geliştirmek için öğrenciyi merkeze almakta, aynı zamanda öğretmene denetleyici, gözlemci, yol gösterici, destekleyici ve teşvik edici bir rol vermektedir (Sakız, 2018). Kapsayıcı eğitim programı, öğrencinin başarısını, başarının kalıcılı̆̆ını, kalıcılığın kullanılabilirliği ve bu kullanılabilirliğin özümsenmesi için öğretmen ve öğrenciye özerk bir rol sunarak program içerisinde kendi uyarlama ve düzenlemelerini yapma imkânı vermektedir. Kapsayıcı öğretim programı, öğretmene, öğrenciyle iç içe, bazı kazanımları serbest bir şekilde farklı bir yolla kazandıracağı gibi, öğrenciye de öğrenme programı üzerinde görüş ve tercihlerini belirtme ve bu sürece katılma olanağı sunar. Dolayısıyla kapsayıcı öğretim programı sayesinde öğrenci kendi dilini de daha bilinçli ve amaçlı bir şekilde öğrenerek, hem kendi dilindeki hem de hedef dildeki eksikleri fark etme imkânı bulmaktadır (Booth \& Ainscow, 2002).

Kapsayıcı eğitim ve öğretim programlarının tüm öğrencilerin gelişim ve öğrenme düzeyini hedefleyerek öğrencilere nitelikli eğitim firsatları sunduğu gerçeğinden yola çıkarak bu çalışmada, Türkiye eğitim sistemine bir model olabilecek İngilizce dersi öğretim programları tasarlanmıştır. $\mathrm{Bu}$ çalışmada hazırlanan program, öğrencilerin İngilizce dersine olan ilgisini arttırarak, yaparak, yaşayarak, deneyim kazanarak, ihtiyaçlarına cevap verip, onlara iletişim becerisini kazandırmayı amaçlamaktadır. Bu amaçla bireylerin okula değil, okulların bireye uyum sağlamasını esas alıp kapsayıcı eğitimin eğitsel gerekçesini karşılamayı amaçlamaktadır (Ceyhan, 2016). Bunu yaparken, öğrenciyi teknolojiyle iç içe tutup, teknoloji kullanma kabiliyetlerini artırmak da bir diğer hedefidir. Her birey için bu teknolojik gereksinim farklı olabilir. Bu gereksinimler sadece okulda değil evlerinde de temin edilmelidir. Bireylerin ihtiyaçlarına özgü bu teknolojinin tespiti ve temin edilmesi de amaçlanmaktadır. Dolayısıyla bu program, kapsayıcı eğitimin bireyin ihtiyaçlarına ve istediklerine cevap vererek öğrencilere özgü içerikler hazırlanması gerektiği ilkesini karşılamayı temele alır (Sakız, 2016). 
Kapsayıcı eğitimin bireyin kişisel, toplumsal ve ekonomik durumuna bakılmaksınız, her bireye nitelikli eğitim verilmesi gerektiği ilkesi hazırlanan programın önem verdiği bir noktadır (Gürgür \& Rakap, 2019). Geliştirilmiş olan bu program, öğrencilerin zihinsel gelişim düzeylerine uygun olmasının yanı sıra, eğitimin her birey için bir hak olduğu çizgisinden ayrılmadan, akademik yeterlilik bakımından farklı düzeylerde olan, çeşitli maddi ve manevi olanaklardan yoksun olan bireylerin de eğitimden tam olarak faydalanmasını sağlamak için, onları okulda ve sınıfta evlerindeymiş gibi hissetmelerini sağlayacak firsatları sunmaktadır.

Öğrencilerin dil öğrenme ilgi, tutum ve becerilerini etkin tutarak, konuşma, okuma, yazma, dinleme becerilerini geliştirmek programın özünü oluşturmaktadır. Öğrencilerin ilgi, tutum ve becerilerini geliştirmek için yapılacak her türlü eylem ve hazırlanacak materyal, kapsayıcı eğitimin yaparak ve yaşayarak öğrenmenin yaşam boyu devam ettiği ilkesiyle iç içedir. Kapsayıcı eğitim, bireylerin eğitim ihtiyacının sadece belirli bir program veya planla belirli bir zaman dilimine sıkıştırılmaması gerektiğini, eğitimin yaşam boyu devam eden bir ihtiyaç olduğunu vurgular (Cole, 2008). Bu bağlamda kapsayıcı İngilizce dersi öğretim programı, yapılandırmacı öğrenme modelinin önemli savunucularından olan Piaget ve Vygotsky'nin görüşleriyle paralellik gösterir. Yapılandırmacı öğrenme, bireysel farklılıklara dikkat ederek, her bireyin ilgi, tutum ve becerilerinin farklı olduğunu vurgular (Erdem \& Demirel, 2002). Ayrıca eğitimin yaşam boyu devam ettiğinin vurgulanması ve öğrenmedeki amacın öğrenmenin öğrenilmesi gerektiği olduğu bu yaklaşımın önemli diğer noktalarıdır (Arslan, 2007).

Öğretim programlarında öğrencilerin bireysel farklılıklarına dikkat edilerek, ilgi, tutum ve becerileriyle uyumlu olarak görsel ve işitsel aktiviteler hazırlanıp, hedef kazanımların elde edilmesinde kullanılması oldukça önemlidir. Bu aktivitelerin gerçekleştirilmesini sağlamak için ihtiyaç duyulan teknolojik materyal ve kitapların edinilmesi gerekmektedir. Nitekim kapsayıcı eğitimin adalet ilkesi, her bireyin ihtiyaç duyduğu eğitimi, bireyler arasında herhangi bir eşitsizliğe yol açmadan adaletli ve eşit bir şekilde, her bireyin nitelikli eğitime erişebilmesini savunur (Sakız, 2018). Bireylere ihtiyaç duymaları halinde teknolojiden ve bu materyallerden faydalanması için firsatlar tanınması gerekmektedir. Bireyler ekonomik olarak birçok olanaktan yoksun olabilir. Ayrıca fiziksel olarak dezavantajlı bir durumda da olabilir. Bu durumu ortadan kaldırmak için onlara evlerinde sunulan olanaklar okullarda da sunulmalıdır.

Kapsayıcı eğitim, tüm öğrencilerin aynı eğitim programının farklılaştırılmış ve uyarlanmış versiyonlarına erişmesini öngörmekte, her bireyin müfredata etkin katılımını sağlamak adına da öğrencilere zaman zaman bireysel destek verilmesi gerektiğini ifade etmektedir (Sakı, 2016). Eğitim programlarının bireyin ihtiyaçlarını dikkate alarak programın farklı bireysel ihtiyaçları karşılayacak şekilde tasarlanması, bireylerin hazır bulunuşlulukları ve öğrenme seviyeleri arasındaki farklılığa dikkat 
edilmesi ve herkesin eğitim müfredatından faydalanmasının sağlanması önemlidir. Her birey farklı bir öğrenme seviyesi ile eğitim öğretim döneme başlar (Oral, 2016). Sınıflarda, diğer öğrencilere göre akademik olarak daha başarılı olan öğrenciler ile öğrenme hızı daha düşük öğrenciler arasında akran işbirliği gibi yöntemleri kullanmak, bazı öğrencileri eğitimden ve sınıftan soyutlamamak için seviyelerinin tespit edilerek her ünite ve kazanım için bireysel uyarlamalar yapmak (örn. farklı ödevler ve projeler vermek) tüm öğrencilerin eğitimden faydalanma düzeyini artırabilir (Sakız, 2018). Ayrıca her ders veya ünite için sınıf planı üstte bahsedilen uyarlama ve düzenlemeler yoluyla oluşturulabilir. Dolayısıyla hazırlanan bu program, eğitim-öğretim başlangıcında gelişim ve öğrenme düzeyleri farklılık gösteren bireyleri ayrıştırmadan, hepsinin ortak konularda farklı yollarla bilgi edinmesini de amaçlamaktadır. Bunu bireyselleştirilmiş ders planı, sınıf planı ve bireyselleştirilmiş ödev ve projelerle yapmayı hedeflemektedir.

Öğretim programının bireylere göre uyarlanabilmesini sağlayan yöntem ve teknikler, sınıf planı, ödev ve projeler, her öğrencinin derse katılımı ve bilgi edinmesi için önemlidir. Kapsayıcı ilkelere göre bu stratejiler, öğrencileri genel öğretim programından ayıran ve farklı kazanımlar ile eğitilmesi yoluyla ayrıştırılmasına neden olacak şekilde değil, kendi ihtiyaç, özellik ve tercihleri doğrultusunda öğrenim yapılmasını sağlamaktadır (Sakız, 2017). Öğrenci, seviyesine göre hazırlanmış olan ders, ödev ve projeyi, öğrenci daha istekli bir şekilde yapabilmektedir. Bu istek ve arzuyla, her birey özünde var olan potansiyeli maksimum seviyeye çıkartıp, bireyi daha katılımcı yapmayı amaçladığı gibi öğrenmeyi daha kalıcı ve sürekli hale getirmeyi de amaçlamaktadır. Bu yolla akademik gelişim hızı yüksek olmayan öğrencilerin de derste başarılı olabileceğinin farkına varması sağlanabilir. Ayrıca bütün öğrencilerin derse katılımıyla ders, hem öğrenci hem de öğretmen için daha zevkli bir hale gelmektedir.

Günümüzde İngilizce, ortak uluslararası bir dil konumuna gelmiştir. Bu durum, öğrencilerin farklı kültürlerle iletişime geçmesinde İngilizce öğrenimini gerekli kılmaktadır. Ayrıca günümüz teknolojik gelişmeleri ve iletişim daha çok yaygınlaşarak, eğitimde, sağlikta, ticarette, ulaşımda ve daha birçok olanda ortak bir iletişim aracı olarak da İngilizceyi ön plana çıkarmıştır. Kapsayıcı öğretim programlarında İngilizce'nin uluslararası ortak bir dil olarak görülüp, bu kadar çok farklı alanlarda kullanılması nedeniyle, öğrencilerin bu gibi farklı alanlarda dil kullanma kabiliyetlerinin geliştirilmesi için proje ve görev odaklı bir görevlendirmeyle, işbirlikçi bir öğrenme anlayışı da benimsenmektedir.

Kapsayıc1 eğitim, bireyleri ırk, din, dil, renk, kültür farklılığı gözetmeksizin nitelikli eğitimin ve özelde öğretim programının her bireye adil bir şekilde, ihtiyaç ve ilgiler doğrultusunda ulaştırılmasını savunur (Sakız \& Sarıcalı, 2018). Bu bağlamda hazırlanan söz konusu program, sosyal ve kültürel farklılıkları gözeterek, bireyin varlığına ve kişiliğine saygı duyarak, bireylerin ekonomik gücündeki farklılıklar nedeniyle eğitime ulaşım eksikliğine neden olacak ekonomik zorunluluktan sıyrılmış ve teknolojik gereksinimleri sağlayarak hazırlanmış, bireyi sistemin kendisi olarak görüp, her bir bireyi 
ayrı ayrı kapsamayı amaçlamıştır. Dolayısıyla ders planı, sınıf planı, ders ve projeler bireyleştirilmiş olabileceği gibi, sınıfta uyumun ve ahengin sağlanması için işbirlikçi bir öğrenme planına da başvurulması gerekmektedir.

\section{PROGRAMIN VIZYYONU}

Bu çalışmada tasarlanan ortaöğretim kapsayıcı İngilizce dersi öğretim programı, yabancı dili kullanarak öğrencilerin kendini anlatabilmelerini, farklı kültürlerle iletişime geçebilmelerini ve kendilerini kültürel, düşünsel ve sosyal olarak geliştirmelerini amaçlamaktadır (MEB,2015). Öğrencilerin İngilizce'yi her türlü iletişim yolları ile kullanabilen, yazabilen, okuyabilen, dinleyebilen ve konuşabilen bireyler olarak yetiştirilmesi amaçlanmaktadır. Öğrencilerin bu iletişim yöntem ve araçlarını kullanabilmelerinin yanı sıra, öğrendiklerini gerçek yaşamda uygulayabilmesi, öğrenim hedeflerine ulaşılması bakımından önemlidir.

Öğrencilerin öğrenme hedeflerine ulaşmaları sağlanırken, yeni hedefleri ön bilgileriyle ilişkilendirmeleri, öğrendiklerini bir sonraki kademe ve seviyeye aktarabilmeleri oldukça önemlidir (Cole, 2008). Dolayısıyla bu programda da öğrendiklerini bir sonraki seviyeye aktarabilmesi için, öğrencinin öğrenmeyi öğrenmesi sağlanarak hayat boyu öğrenme sürecinin devam etmesi hedeflenmiştir. Öğrenmeyi öğrenen öğrencinin, sorumluluklarını bilerek, bilgi, tutum ve becerilerini geliştirmesi, teknolojiyi etkili bir şekilde kullanarak yenilikleri takip etmesi düşünülmektedir (Gürgür \& Rakap, 2019). Bütün bu becerilere sahip olan öğrencinin, kendine güven duygusu artarak, olaylar arasındaki ilişkiyi daha iyi anlayıp yorumlayabilir ve karşılaştığı sorunları daha rahat çözebilir.

\section{PROGRAMIN YAPISI}

\section{Programın Genel Amaçları}

Kapsayıcı eğitim farklılıklara saygıyı, farklılıkların kabulünü ve bu farklılıkların öğrenme ve öğretme yöntemlerinin zenginleştirilmesi adına bir firsat olarak değerlendirilmesini öngörür (Oral, 2016). Bu nedenle kapsayıcı eğitim programı da hem hedef dilin kültürüne hem de öğrencilerin birbirlerinin kültürlerine saygı duyarak, İngilizce aracılığıyla kültür farklılıklarını ve kültürlere saygılı olmayı amaçlar.

Kapsayıc1 öğretim programı, eğitim ve öğretim dönemi başında öğrencilerin seviyelerinin tespiti ve bu yolla öğretim programında yapılacak uyarlama ve düzenlemeleri önemli bir etkinlik olarak değerlendirmektedir. Programda hedef dilde verilen kültürel, insani ve sosyal kapsama dâhil örneklerle, hedef dilin kültür altyapısı kazandırılarak, hem hedef dilin özünün anlaşılması hem de dört dil becerisine her öğrencinin anlaşılır ve kalıcı olarak erişmesi hedeflenir (MEB,2015). Ayrıca programın uygulama sürecinde her bir öğrenci temelinde öğretim plan, yöntem ve tekniklerin kullanılarak, her bireye ayrı ayrı değer verilerek her bireyin maksimum potansiyeli ortaya çıkarılır. Böylelikle her bireyin hedef dilde 
kendi seviyesine göre söz varlığını geliştirmesi, dinleme, okuma, yazma ve konuşma (dört dil becerisi) becerisini kazanması, hedef dilde fikir üretmesi ve fikirleri yorumlaması amaçlanmaktadır.

Kapsayıcı eğitim programı, bireylerin dezavantajlı gibi görünen fiziksel, ekonomik veya toplumsal farklılıklarını olduğu gibi kabul ederek her bireyi öğrenme ortamına ve öğrenme süreçlerine dâhil etmeyi hedefler (Gürgör \& Rakap, 2015). Bunu yaparken, öğrenciye öğrenme ortamları tasarlama, öğretim planı hazırlama ve öğretim sürecine katılım imkânı da vermektedir. Kapsayıcı öğretim programı, okulu, sınıfı ve eğitim-öğretim faaliyetini yerine getirirken kullanılan her türlü materyal, altyapı, teknolojik donanım ve web içeriklerini öğrencinin farklılıklarına, ihtiyaçlarına ve isteklerine göre tekrar düzenlemeyi hedefler (Ceyhan, 2016).

\section{Programın kapsamı}

Kapsayıcı eğitim, öğrencilerin akademik, fiziksel veya sosyal olarak bireysel farklılıklarını gözeterek, her öğrencinin eğitimden faydalanması gerektiğini ifade edip ve eğitimin bütün öğrencileri kapsaması gerektiğini vurgular (Sakız, Woods, Sart, Erşahin, Aftab, Koç \& Sarıçam, 2015). Bu nedenle hazırlanan kapsayıcı İngilizce dersi öğretim programı, akademik, zihinsel, bilişsel, duyuşsal ve psikomotor alanlardaki öğrenme ve gelişimi hedefleyerek bütün öğrencileri kapsamaktadır. Her bireyin kendi akademik seviyelerine göre bireyselleştirilmiş eğitim anlayışıyla, öğrencilerin iletişim becerilerini ve dört dil becerisini geliştirerek, hedef dilin kültürünü tanımayı ve kendi kültürlerini karşıya aktarmaya yönelik kazanımları içerir. Hazırlanan bu öğretim programı, öğrenci özelliklerinin çeşitliliklerine göre göre farklılaştırılabilecek ödev ve projelerin geliştirilmesini öngörmektedir. Ayrıca öğrencilerin sorumluluk almaktan kaçınmadan, işbirliği içerisinde birbirlerine destek olarak kendi öğrenme ortamlarını oluşturmalarına olanak tanır. Öğrenciye bunu yaparken her türlü teknolojik altyapı sunulur.

\section{Öğrenme Alanları}

Dil öğrenme, dinleme, okuma, yazma ve konuşma becerilerinden oluşmaktadır (Demirezen, 2003). İngilizce dersi kapsayıcı öğretim programı, bu becerilere herhangi bir öncelik sırası verilmeden, hepsine aynı anda ama öğrencilerin seviyelerine, bireysel farklılıklarına, ilgi alanlarına göre ve öğrenme süreçlerinin gerektirdiği bireysel süre dikkate alınarak tasarlanmıştır (Sakız, Woods, Sart, Erşahin, Aftab, Koç \& Sarıçam, 2015). Ancak her ünite ve temanın gerektirdiği bilgi ve beceriye göre bu sıra değişebilmektedir. Her bir öğrenci için gerçekleştirilecek olan seviye ve ihtiyaç tespit süreçleri de öğrencilere bireysel olarak hazırlanan öğretim programlarında bu becerilerin nasıl geliştirileceğine dair 1şık tutacaktır. Öğrencilerin bu becerileri en iyi şekilde kazanmaları için etkileşim ve işbirliği kurmaları gerektiği göz önünde bulundurarak, görsel ve işitsel iletişim araçları kullanılmıştır (Düşün, 2016). Öğrencilerin duyduğunu anlama ve cevap verme yeteneklerini geliştirmek için diyalog çalışmalarına önem verilmiştir. Aynı zamanda yazma ve okuma becerilerinin gelişmesi için dilbilgisi kuramlarına önem verilerek, çeşitler metinler ve okuma parçalarılla okuma (reading) ve yazma (writing) 
becerilerinin üzerinde durulmuştur (MEB, 2011). Öğrencilere verilen çeşitli proje ve ödevlerle, ayrıca sınıf içerisinde yapılan bireysel ve grup aktiviteleriyle de konuşma (speaking) becerisinin de geliştirilmesi amaçlanmıştır. Bu dört dil becerisini kullanarak kendini anlatma ve karşıdaki kişiyi anlama becerisi geliştirilmeye çalışılmıştır. Ayrıca bu becerilere yardımcı olacak diğer yan becerilerden de bahsetmek gereklidir. Bu beceriler ayrı ayrı başlıklar altında aşağıda belirtilmiştir.

\section{Dinleme}

Çağımızda teknoloji, ticaret gibi birçok nedenle iletişim çok büyük önem kazanmıştır (Kuyucu, 2017). Bu iletişimin sağlanması için dünyamızda evrensel dil olarak görülen İngilizcede, dinleme becerisinin kazandırılması çok önemlidir. Dinleme, karşıdaki kişinin öne sürdüğü düşünceyi anlamak, yorumlamak ve mantıklı bir şekilde cevap vermek için önemlidir. Bu nedenle programda farklı konulardan ve ortamlardan birçok dinleme aktivitesi hazırlanmalıdır.

İngilizce dersi kapsayıcı öğretim programı her bireyin nitelikli eğitim alma ve öğretim programından faydalanma hakkını vurgulamaktadır. Bu nedenle, bu programda hazırlanan dinleme aktiviteleri ve hedeflenen dinleme becerilerinin her bireye hitap etmesi amaçlanmıştır (Sakız, 2015). Örneğin işitme engeli gibi çeşitli zorluklar yaşayan öğrencilerin dinleme becerilerini kazanması için gereken bireysel önlemler alınıp, sınıf, okul ve ev ortamında gerekli teknolojik altyapı ve doküman temini sağlanmalıdır. Ayrıca öğretmenler ve okul idaresi işitme engeli olan çocukların eğitiminde dikkat edilmesi gerekenlerle ilgili eğitilmeli ve gerekli bilgilendirmeler yapılmalıdır (Asar, 2020).

Farklı dinleme metinleri hazırlamak, farklı kelimelere maruz kalıp, o kelimelerin telaffuzuyla ilgili kulak dolgunluğu kazanmak için önem arz etmektedir. Dinleme metinleri, bireyselleştirilmiş öğretimin gereği olarak, kişiye özgü, günlük hayatta yaygın bir şekilde kullanılan veya belli bir alana özgü diyaloglarla zenginleştirilerek, ünitelere, kazanımlara ve temalara uygun olarak hazırlanmalıdır (Oral, 2016).

Örnek diyaloglar dinleme öncesi verilerek öğrencinin dinlenilecek metin veya diyalogla ilgili hazırbulunuşluğu artırılır. Ayrıca Eğitim Bilişim Ağı (EBA) gibi platformlardan faydalanarak dinleme öncesi pekiştirme yapılabilir. Dinleme esnasında öğretmenlerin vereceği yönergeler çok önemlidir. Dinleme sonrasında ise öğrencinin dinleme öncesi ve dinleme esnasındaki dinleme becerisini farklılığı tespit edilerek, kazanımın yeterli bir şekilde aktarılamadığı öngörülürse, ders farklı yöntem, ödev veya projelerle öğrenciye tekrarlanır.

İngilizce dersi kapsayıcı öğretim programı için, belirtilen dinleme kazanımlarına ulaşılabilmesi adına ihtiyaç duyulan teknolojik materyaller ve dokümanların özenle hazırlanması önemlidir (Sakız \& Sarıcalı, 2018). Ses kayıtları, dinleme bantları, CD’ler uzman kişiler tarafından hazırlanıp hedef kelimelerle ve konularla bağlantılı bir şekilde hazırlanmalıdır. 


\section{Konuşma}

Bir dilde konuşma becerisi kendini ifade edebilmek için oldukça önemlidir. Konuşma becerisinin anlamlı hale gelmesi için birçok bileşen vardır. Bunlardan birincisi kelimeyi doğru telaffuz (pronouncation) etmektir. Bu beceriye sahip olmak konuşmanın karşı tarafta doğru anlaşılmasına yardım eder. Bir kelimenin doğru bir şekilde telaffuzu, anlatılmak istenen konuyu ayrıntılarıyla karşıya anlatılmasını sağlar. Ayrıca konuşmayı tekrardan kurtarır, konuşmaya akıcılık ve devamlılık katar (MEB, 2011).

Konuşmayı etkileyen bir diğer unsur, konuşmanın akışına ve konuya uygun olarak, kullanılacak olan jest ve mimikler, ayrıca konuşurken noktalama işaretlerine ve cümlenin öğelerine dikkat etmektir (Demirezen, 2003). Konuşurken cümlelerin ve kelimelerin iç içe geçmesini engellemek için, konuşmanın akıcılığı ve anlamlılığını artırmak için bu kurallara da uymak önemlidir.

Konuşmayı etkileyen önemli unsurlardan biri de konuşma korkusudur. Öğrenci yanlış bir şey söylemek, karşıdaki birey tarafından iyi anlaşılamamak, yetersiz olacağını düşünmek gibi birçok sebepten ötürü konuşmaya korkarak yaklaşabilir. Dolayısıyla hazırlanan program bu korkunun ortadan kaldırılmasına teşvik edici uygulama ve pekiştireçlerle desteklenmelidir. Bu korkunun üstesinden gelmek için öğretmen desteği de bir o kadar önemlidir. İngilizce dersi kapsayıcı eğitim programı, bütün bu noktalara dikkat ederken, fiziksel olarak konuşma zorluğu çeken ve öğrenme hızı seviyesi farklı olan öğrencilerin için bireyselleştirilmiş konuşma etkinlikleri ve görevleri öngörür (Sakız \& Woods, 2015). $\mathrm{Bu}$ etkinlik ve görevler, teknolojik altyapıyla hazırlanmış web tabanlı uygulamalar ve materyallerle desteklenmektedir. Ayrıca öğretmen ve okul yönetiminin bu özel durumdaki öğrencilerin eğitiminde gerekli eğitim ve seminerleri alması gerekmektedir.

$\mathrm{Bu}$ programda hazırlanan konuşma etkinlikleri üstte yer verilen önemli noktalara dikkat edilerek hazırlanmıştır. Konuşma öncesi, konuşma esnası ve konuşma sonrasında da etkinliklerle, çeşitli ödev ve projelerle desteklenen bu program konuşma (speaking) becerisinin önemine uygun olarak ayrıntılı bir şekilde hazırlanmıştır. Konuşma öncesi etkinliklerle, öğretmen öğrenciyi konuşmaya hazırlar. $\mathrm{Bu}$ seviyede öğrenci EBA gibi çeşitli teknolojik materyal ve uygulamalarla desteklenir.

Konuşma öncesi etkinliklerle, öğretmen öğrenciyi konuşmaya hazırlar. Bu seviyede öğrenci EBA gibi çeşitli teknolojik materyal ve uygulamalarla desteklenir. Konuşma esnasında öncelikle, öğretmen öğrencinin konuşma korkusu ve heyecanını giderici dönütler verip öğrenciyi rahatlatmalıdır. Öğrenciye konuşma aktivitesiyle ilgili kelimeler, konular ve varsa benzeri diğer etkinlik, ödev ve temalar hatırlatılmalıdır. Öğrenciye başlaması için gereken vakit verilmeli gerekirse konuşmaya önce öğretmen kendisi başlamalıdır (Cole, 2008). Konuşma sonrasında da öğrencinin konuşma esnasında yaptığı hatalar tespit edilerek, yaptığı hatalara yönelik yeni ödev ve projelerle hataların düzeltilmesi sağlanmalıdır. 


\section{Telaffuz (Pronunciation)}

Telaffuz konuşma becerisi üzerinde çalışırken üzerinde durulması gereken bir diğer alt beceridir. Öğrenci kelimeleri doğru bir şekilde telaffuz edemezse, söylemek istediği şey anlaşılamayabilir veya yanlış anlaşılabilir. Bu gibi yanlışların önüne geçmek için telaffuz özelliklerine dikkat edip, bu yönde öğretmenlerin çalışma yapması önemlidir.

Öğretmen öğrencinin derse katılımına yardımcı olması için, öğrenciyi bölmemek ve motivasyonunu düşürmemek için konuşma esnasında düzeltme yapmaktan kaçınmalıdır. Konuşma öncesi aktivitelerde hedef kelimelerin telaffuzunu doğru bir şekilde vermeli, konuşma etkinliği sonrasında da yanlışlıklarla ilgili çalışma yapmalıdır.

\section{Okuma (Reading)}

Dil öğreniminde okuma becerisini geliştirmek oldukça önemlidir. Okuma becerisi kelime bilgisi, cümle kurma, söz öbekleri oluşturma, kendini doğru ifade edebilme, bilgiye ve farklı kültürlere erişimde ve daha birçok alanda önemini gösteren, sahip olunması gereken bir beceridir (MEB, 2011). Okuma becerisiyle, öğrenci farklı kültürleri tanıma fırsatı bulur. Bu kültürlerin özellikleriyle ilgili bilgi araştırması yaparken, farklı sitelerdeki metinleri anlama ve fikir üretme yeteneğine sahip olacaktır.

Dünyanın farklı bir bölgelerinden haber almak için haber siteleri, dergi veya metinleri okumak için okuma becerisinin önemi tartışılmaz. Ayrıca kişinin sosyal, kişisel ve eğitsel becerisiyle ilgili gerekli siteleri takip edip anlayabilmesi, ayrıca bu bilgilerden kendine çıkarımlarda bulunabilmesi için de okuma becerisi oldukça önemlidir (MEB, 2011).

Okuma becerisini geliştirmekte kelime bilgisine sahip olmak önemlidir. Ayrıca okuma etkinliği yaparken hâlihazırda sahip olduğunuz kelime bilgisini pekiştirebilir ayrıca yeni kelimeler öğrenilebilir. $\mathrm{Bu}$ kelimelerin anlamlı bir şekilde kullanılması ve cümle içerisinde aldığı farklı anlamları görebilmek içinde okuma becerisi önemlidir. Kelimelerin anlamlı bir şekilde kullanıp doğru yorumladıktan sonra söz öbekleri oluşturma ve cümle oluşturma ve okuduğumuz metindeki cümleleri anlamak için okuma yine önem arz etmektedir (MEB, 2015). Okuma becerisine sahip olan bir öğrenci aynı zamanda okuduğu metinden doğru anlamlar çıkartıp, yorumlayabilir. Bu beceriye sahip olan öğrenci kendini doğru ifade edebilir. Öğrenci böylelikle anlatım gücünü geliştirmiş olacaktır. Okuduğu metindeki düşünceler hakkında yorum yapıp onlara katıldığı yerleri belirtebileceği gibi, bu düşünceleri eleştirebilecek aynı zamanda yeni fikirler öne sürme kabiliyetine sahip olacaktır (Arslan, 2007).

Kapsayıc1 İngilizce dersi öğretim programı, okuma güçlüğü çeken öğrenciler için onların öğrenme hızına uygun olarak çeşitli aktivite ve etkinliklerle donatılmıştır. Okuma güçlüğü çeken öğrenciler için özel olarak hazırlanmış olan materyaller, ders kitapları ve teknolojik aletlerle bu 
öğrencilerin okuma egzersizleri yapması sağlanmakta ve okuma becerisini kazanmaları hedeflenmektedir (Sak1z, 2018).

Öğrencinin okuma becerisini en iyi şekilde edinip, bu becerinin kalıcılığını sağlamak için üniteler, etkinlikler ve temalar özenle hazırlanmıştır. Okuma öncesi, okuma esnasında ve okuma sonrasında öğrencinin takibi yapılarak eksiklikler giderilmeye çalışılmıştır. Okuma öncesi aşamada öğretmen, okuma konusuyla ilgili kelime bilgisini temin edip çeşitli okuma parçalarını sunar. EBA gibi çeşitli eğitimsel siteden de faydalanarak, öğrencinin evinde de bu bilgileri edinip pekiştirmesini sağlar. Okuma esnasında, öğretmen okuma metnini verir. Çeşitli etkinliklerle okuma becerisi hedeflerine ulaşmaya çalışır. Okuma metniyle ilgili belirtilen etkinlikleri uygular. Okuma sonrasında, öğretmen eksik görülen noktalarda ilgili öğrenciyi ödev, proje ve etkinliklerle tekrar görevlendirir.

\section{Yazma (Writing)}

Yazma, kişinin kendini ifade edebilmesi için dil öğreniminde sahip olunması gereken bir diğer beceridir. Kişi e-posta göndererek, mektup yazarak, blog sayfa açarak, özgeçmiş doldurup ödev yaparak ve daha birçok şekilde kendini ifade edebilmesi için yazma becerisi önemlidir (MEB, 2015). Yazma becerisinin etkili bir şekilde edinimini sağlamak için, bu programdaki ünite etkinlik ve temalar özenle hazırlanmıştır. Öğrenciye yazma öncesinde, yazma esnasında ve yazma sonrasında çeşitli etkinlik ve temalarla yazma becerisini kazandırmak amaçlanmıştır.

İngilizce dersi kapsayıcı öğretim programı, yazma güçlüğü veya okuma güçlüğü gibi durumlardan dolayı okuma ve yazma süreçlerinde zorluk yaşayan öğrenciler için özel olarak hazırlanmış yazma etkinlikleri ve materyalleri temin etmektedir (Sakız \& Woods, 2015). Ayrıca sınıf ortamı buna uygun olarak hazırlanıp bu durumda olan öğrenciler için rahat bir ortam oluşturmayı hedeflemektedir.

\section{Dilbilgisi (Grammar)}

Dilbilgisi, öğrencinin yazma becerisini doğru bir şekilde kullanması için kazandırılması gereken bir diğer beceridir. Öğrenci dilbilgisi becerileri doğru kullanamazsa, cümlenin zamanını yanlış kullanmak, yanlış bağlaç kullanmak, cümle öğelerini kullanırken hatalar yapmak gibi birçok yanlışa düşebilir (MEB, 2015). Dilbilgisi kurallarının eksiksiz bir şekilde verilip kazandırılması bu nedenle çok önemlidir.

Dilbilgisi kurallarını verirken, bu konu kazandırılması gereken ana beceri olduğu izle-nimi verilmemeli, ders dilbilgisi kuralları üzerinden gitmemelidir. Öğrenciye küçük görevlerle, okuma veya yazma aktiviteleri esnasında soru cevaplarla veya konu anlatımında verilen örnek okuma ve yazma görevlerindeki ilgili paragraflardaki dilbilgisi kurallarıyla eşleştirmeleri istenir. 


\section{Noktalama İşaretleri ve Yazım Kuralları (Punctuation and Spelling Rules)}

Yazma becerisini edinirken sadece kelime bilgisi ve kelimeleri doğru kullanmak yeterli değildir. Aynı zamanda, noktalama işaretleri ve yazım kuralları da bir o kadar önemlidir. Cümlenin başının veya sonun belli olmadığı, noktanın yanlış yerde kullanıldığı, satır sonuna gelen cümlenin yanlış bir şekilde kesildiği, büyük-küçük harfle yazım gibi birçok kurala uymak yazılan metnin daha iyi anlaşılmasına olanak tanıyacaktır (MEB, 2015).

\section{PROGRAMIN UYGULANIŞI}

Ortaöğretim İngilizce Dersi Kapsayıcı Öğretim Programı "Diller İçin Avrupa Ortak Başvuru Metni’nde belirtiği üzere A1, A2, B1, B2, C1, C2 seviyelerine uygun olarak hazırlanmıştır. Hazırlık, 9, 10,11 ve 12 sinıf seviyelerinde, programda belirtilen farklı lise türlerine göre ayrı ayrı tablolar halinde, kazandırılması hedeflenen dinleme, yazma, konuşma ve alt beceriler ile birlikte amaçlar-kullanılan dil ve materyaller başlıklarıyla tablolar halinde belirtilmiştir.

Okulların bir yarı dönemde 18 hafta eğitim-öğretim yaptığı ön görülmüştür. İngilizce için ayrılan haftalık ders saati 4 saattir. Her kademede öğrenciler eğitim öğretim yılına başlarken öğretmenler tarafından seviye tespit değerlendirmelerine tabi tutulur. Seviye tespit değerlendirmeleri her bir kazanımın ayrı ayrı değerlendirilmesiyle, öğrencinin okuma, yazma, konuşma ve dinleme becerisine "sahiptir" -"kısmen sahiptir"- "sahip değildir" olarak her bir öğrenci için bireyselleştirilerek değerlendirmeler yapılır. Öğretmen, öğrencilerin performans puanlarını bütün y1l takip etmek için öğrencilere özgü kişisel dosyalar hazırlayarak saklar. Seviye tespit değerlendirmeleri sonucunda elde edilen sonuçlara göre öğrencilere özgü bireyselleştirilmiş etkinlik, kazanım, ödev ve projeleri dönem içerisinde öğrencilerin yapmasıyla verilmek üzere tarihler belirlenir.

Ünite temelli çalışmada, bu değerlendirme sonuçlarına göre belirlenen etkinlikler öğrencilere ayrı ayrı sunulur. Seviye tespit değerlendirmeleri okulun açıldığ ilk hafta yapılır. İkinci hafta normal ders akışına devam edilir. Altyapısı yeterli olan okullarda öğrenciler belirlenen bu sınav sonuçlarına göre sınıflara ayrılır. Altyapısı yeterli olmayan sınıflarda öğretmen, kapsayıcı eğitimi yerine getirmenin gerekliliğiyle bireyselleştirilmiş eğitim programını daha dikkatli ve ayrıntılı bir şekilde uygulamaya devam eder. Seviyelere göre A1, A2, B1, B2, C1, C2 seviyelerine ayr1lan öğrencilere, seviyelerine göre düzenlenmiş temalardan uygun olanlar seçilir. Nakil ile gelen öğrencilerde öğrencinin beyanına bakılarak süreç içerisinde değerlendirme yapılır. Veli ve öğrencinin talebi doğrultusunda öğrencinin durumunun tekrar değerlendirilmesi mümkün olur.

Öğretmen ilk hafta seviye tespit değerlendirmesini yaptıktan sonra, öğrencilere seviyelere göre her hafta ve her ünitede olacağı gibi etkinlikler ve ödevlerle görevlendirmeye başlar. Bu görevlerin bazıları geçmişten gelen eksiklerini kapatmaya yönelik olduğu gibi ünitenin amaçlarına ulaşmada 
başarılı olmasını sağlayacak şekilde verilecektir. Verilen her ödev, yapılan her etkinlik, kazandırılması hedeflenen her beceri ve amaçlanan her ünite, süreç öncesinde, süreç esnasında ve süre sonrasında değerlendirmeye tabi tutulur.

Öğrencilere her dönem iki değerlendirme yapılır. Bu sınavlar okuma, yazma, dinleme ve konuşma becerileri ayrı ayrı değerlendirilir. Öğretmen isterse bu becerilere grammar bilgisini de ekleyebilir. Puanlama öğrencinin aranan becerilere sahiptir-kısmen sahiptir-sahip değildir olanlar değerlendirilmesi ve her bir öğrencide aranan niteliklere göre değerlendirilmesi önemlidir.

\section{TEMA VE İÇERÍK ÖNERILLERI}

Yabancı dil eğitim programında hazırlanan tema, içerik ve kazanımlar, öğrencilerin gelişim düzeylerine uygun olarak hazırlanmıştır. Dönem başında yapılan seviye tespit değerlendirmelerinden, öğretmenler öğrencilerin seviyelerine uygun olarak, tema ve içerikleri seçmeye özen göstermelidir.

Kapsayıcı öğretim programlarına uygun içerik belirlenirken çeşitli hususlar dikkate alınmalıdır. Seçilecek konuların toplumsal, kültürel ve ahlaki değerleri dikkate alacak şekilde düzenlenmesi gerekmektedir (Sakiz, 2017). Bu durum, toplum paydaşlarını artırdığı gibi öğrencilerin gelişim ve öğrenme düzeylerinin artırılması adına ortak bir çaba üretilmesini sağlar (Sakiz, 2018). Öğrenmenin pekiştirilmesi ve devamlılığını sağlamak için, ders materyalleri özenle seçilmelidir. Kullanılacak cd, kitap, metin gibi ders materyalleri öğrencinin ilgisini çekmesi gerektiği gibi, programın amaçlarına ve öğrenci seviyesine uygun olarak seçilmelidir.

Seviye tespit değerlendirmelerine göre belirlenen dil yeterlilik düzeylerine göre kazanımlar belirlenmeli, okuma, yazma, dinleme ve konuşma becerilerini dengeli bir şekilde kapsayan içerikler düzenlenmelidir. Okuma, dinleme, konuşma ve yazma becerileri için güncel konulardan seçilip, gerçek hayattan örnekler içermelidir. Bu becerilerin geliştirilmesi için farklı konular seçilip, posterlerle, görsel farkındalığı arttırıcı içeriklerle desteklenmelidir. Seçilen konular öğrencilerin seviyelerine göre belirlenmeli, hazırlanacak olan materyallerin kullanışlılığ 1 ve anlaşılırlığı her bireye uygun olarak, bireysel farklılıkların dikkate alınması önem arz etmektedir. Uygulanacak her türlü etkinlik için teknolojinin her türlü nimetlerinden de faydalanılmalıdır. Teknolojik donanım, kapsayıcı İngilizce dersi öğretim programında öngörülen bireyselleştirilmiş öğretim hedeflerine ulaşmakta önemli bir etken olacağı düşünülmektedir (Kuyucu, 2017).

Hedeflere ulaşmak, kazanımların kalııılığını sağlamak ve her bireyin kazanımları rahat bir şekilde edinebilmesi için hedefler yeterli ve öz olması gerekir. Öğrencilerin ve öğretmenlerin rahat bir şekilde bu hedeflere ulaşabilmeleri amacıyla her eğitim öğretim yılı için ulaşılması hedeflenen tema ve içerik yeterli ve öz olacak şekilde aşağıdaki tabloda verilmiştir. 
Tablo 1'de her bir eğitim öğretim y1lı için $\mathrm{A} 1$ ve $\mathrm{A} 2$ düzeyinde 6, B1 ve B2 düzeyinde $8, \mathrm{C} 1$ ve C2 düzeyinde 8 tema ve her tema için ikişer içerik sayısı önerilmiş, aşağıdaki dil yeterlilik düzeylerine göre tema ve içerik tablosunda belirtilmiştir. İlk dönem içim 18 ikinci dönem için 18, 36 haftalık eğitim öğretim yılında, her dönem için 1 er hafta değerlendirmeye, ilk dönemin ilk haftası ise seviye tespit sınavlarına ayrılmıştır. Temalar için ayrılan 33 hafta da öğretmenler, belirlenen tema ve içerik sayılarına uyacaktır ama öğretmenler hangi temaya ne kadar zaman ayıracaklarını ve hangi temaları ve içerikleri seçeceklerini, öğrencilerin ihtiyaç ve özelliklerini dikkate alarak belirleyeceklerdir.

Tablo 1. Dil yeterlilik düzeylerine göre tema ve içerik tablosu

\begin{tabular}{ccc}
\hline Dil Yeterlilik Düzeyleri & Tema Sayısı & İçerik Sayısı \\
\hline A1 & 6 & 12 \\
A2 & 6 & 12 \\
B1 & 8 & 16 \\
B2 & 8 & 16 \\
C1 & 8 & 16 \\
C2 & 8 & 16 \\
\hline
\end{tabular}

\section{ÖĞRETIM ORTAMLARI}

\section{Dil Öğretim İlkeleri}

Öğrenci, öğrendikleri farklı ortamlarda kullanabilme becerisine sahip olmalıdır. İngilizce dersi kapsayıcı öğretim programı, kapsayıcı eğitimin sosyal gerekçesini merkeze alarak, öğrencinin farklı ortamlardaki hazırbulunuşluğunu artırmayı ve insanlarla etkileşim içinde olup, kendini ifade edilmesini hedeflemektedir (Booth \& Ainscow, 2002). Öğrenci böylelikle sınıf gördüğü, örnek yapı, diyalog, yapılarda gördüğü etkinlik veya hedef kazanımları başka bir ortama aktarıp kullanabilme becerisine sahip olabilmektedir. Kapsayıcı İngilizce dersi öğretim programı, öğrenciye öğrenmeyi öğreterek, öğrencinin eğitimine devam etmesi sağlarken, bilişsel, sosyal ve kültürel gelişimine katkıda bulunmasını hedeflemektedir (Sakız \& Sarıcalı, 2018). Öğrenci edindiği bilgileri düzenlemeyi, yorumlamayı ve farklı bir bakış açısı getirerek yeni fikirler üretmeyi öğrenir.

Kapsayıcı eğitimin gereği olarak her birey ayrı ayrı değerlidir. Her bireye dokunulmaya çalışılır. $\mathrm{Bu}$ programda eğitimin herkesin hakkı olduğu ilkesi merkeze alınmış, bu çizgiden dışına çıkmadan eğitimin her bir etkinliği kişinin farklı özelliklerine göre ayrı ayrı değerlendirilerek hazırlanmıştır (Erdem \& Demirel, 2002). Program öğrenci merkezlidir. Bu nedenle öğrenciye kazandırılmaya çalış1lan her bir becerinin öğrenciye katacağı değerler iyice aktarılmalıdır. Öğrenci bu bilgiyi neden öğrenmektedir? Nasıl öğrenecektir? Nerelerde kullanabilir? Bütün bu sorular cevabını da bu programda mutlaka almalıdır. 


\section{Sinıf Ortamı}

Sınıf ortamı, ortaöğretim İngilizce dersi öğretim programının hedeflerine ulaşmak doğrultusunda, kapsayıcı ve bireysel eğitimin gereklerini yerine getirmek için düzenlenmelidir. Sınıf ortamı, yabancı dil becerilerini kazandırılması için bireysel ve grup çalışmalarına uygun bir şekilde düzenlenmeli, bireysel farklılıklar gözetilerek gerekli her türlü materyal hazır bulundurulup, çağdaş eğitimin bir gereği olarak teknolojik bir dönüşüme önayak olmalıdır (Asar, 2020).

Sınıf ortamı öğrencinin kendini rahatsız edecek, öğrenme motivasyonunu olumsuz etkileyecek ortamlardan arındırılmalıdır. Sınıf kuralları, oturma planları, görevlendirmeler sınıf ortamını bozacak tüm etkenlerden uzak bir şekilde düzenlenmelidir.

\section{Öğretmenin Rolü}

Öğretmen öncelikle bütünleştirici ve kapsayıcı olmalıdır. Öğretmen yaptı̆̆ı etkinliklerle, uygulamalarla, oluşturduğu sınıf ortamıyla, öğrencilere davranışı ve yaklaşımıyla, öğrencilerin farklılıklarının bir zenginlik olduğu bilerek, bütün öğrencilerin derse katılımlarını sağlamalıdır. Sınıf düzenini temin edip sınıfta bir güven ortamı oluşturmalıdır (Gürgür, \& Rakap, 2019). Öğretmen, seviye tespit değerlendirmelerinden sonra öğrencilerin eksiklikleri görüp, becerilerini geliştirmek için yönlendirici bir karaktere bürünüp, onlara gerekli etkinli, proje ve ödevleri atamalıdır. Öğretmen lider ve rehber olmalıdır. Bu özelliğiyle öğrencileri hedeflerine ulaşmasında yönlendiricidir. Öğretmen öğrenciye öğrendiklerini deneme ve kullanma firsatı vermelidir. Öğrencilerin öğrenme hedeflerine ne ölçüde ulaştığını böylelikle daha iyi anlama fırsatına sahip olacaktır. Bu şekilde öğretmen öğretmeöğrenme sürecinden daha da iyi sonuçlar alabilir.

Öğretmen etkinliklerin, tema ve içeriklerin amacına ulaşması amacıyla, bireysel farklı1ıkları ve bireysel istek ve ihtiyaçları dikkate alarak ve herkesin kabul edeceği şekilde sınıf kuralları belirlenmelidir (Gürgür, \& Rakap, 2019). Dersin nasıl işleneceği gerekirse öğrencilerle beraber belirlenmeli öğrencilerle paylaşılmalıdır. Ünite veya etkinlik öncesi öğrencileri derse hazırlamak için öğrenciler proje veya ödevlerle görevlendirilmeli, dersten sonra öğrencilerle görülen eksikliklerle ilgili tekrar görevlendirme yapılmalıdır. Ders akışı verimli kullanılmalı, ders esnasında ünite etkinliklerine ulaşmak için her türlü materyal ve teknolojiden faydalanılmalıdır.

\section{Öğrencinin Rolü}

Bu program öğrencinin derse etkin bir şekilde katılımını sağlamak amacıyla, öğrenci merkezli olarak hazırlanmıştır. Öğrenci yabancı dili kullanarak iletişime geçip, sorunları çözme kabiliyetine sahip olması amaçlanmaktadır. Öğrenci böylelikle sorunları anlama, onlara çözümler bulma firsatına sahip olacaktır. Öğrenci merkezli olan bu program öğrencilerin kendi kendine öğrenmeyi öğrenmesini 
amaçlamaktadır. Çevresiyle iletişime geçip sosyalleşmesi gerekir. Öğrenmenin sadece okulda gerçekleşmeyeceğini, yaşam boyu devam ederek hayatın her alanında çıkarılacak dersler ve öğrenme hedefleri olacağını, öğrencilerin görmesi beklenmektedir. Sorumlulukların bilen ve sorumlulukların gereğini yerine getiren bireyler olarak geleceğe 1şık tutmaları gerekir. Bütün bunları yaparken teknolojinin bütün nimetlerinden faydalanmasını bilmeli kendini sürekli güncellemelidir.

\section{PROGRAMIN TEMEL ÖZELLÍKLERİ}

\section{Kapsayıcı Eğitimin İlkeleri ile Uyumluluk}

Kapsayıcı eğitim, eğitimin herkesin eşit bir şekilde faydalanması gerektiğini öne sürerek eğitim herkes için hak olduğunu savunur (Sakız \& Sarıcal1, 2018). Eğitim hiçbir kimsenin ekonomik durumuna, sosyal veya siyasal statüsüne, cinsiyetine, engellilik durumuna bakılmaksınız herkesin hakkıdır. $\mathrm{Bu}$ nedenle eğitim sınıf, okul ve ev ortamında her bir öğrencinin eğitimin bütün olanaklarına ulaşabilmesi için gerekli teknolojik altyapı temin edilip, sınıf ve okul ortamı öğrenci istek ve ihtiyaçlarına göre düzenlenmiştir. Ayrıca eğitim aşamasında, öğretmenin her bir öğrenciye ulaşması için etkinlikler, kazanımlar özenle seçildiği gibi bu etkinlikler ve kazanımları yerine getirmekte kullanılacak uygun materyaller hazırlanmıştır. Eğitimin her bir bireye ulaşabilmesi için sadece öğretmen veya öğrenci ortamlarının değil, öğrencinin iletişimde olduğu okul personeli ve idareye gerekli bilgilendirme ve eğitimler verilmiştir.

\section{Öğrenci Merkezlilik}

Kapsayıcı eğitim, bireysel farklılıkların zenginlik olduğu anlayışıyla, bireylerin etnik köken, dil, kültür, maddi güç, cinsiyet gibi farklılıklarının eğitim alma hakkına etki etmesine müsaade etmeyerek, her bir bireye ayrı ayrı değer verip, onların ilgi, istek ve ihtiyaçlarına cevap vermesi anlayışı hazırlanan programın merkezinde yer almaktadır. Kapsayıcı eğitim, bireylerin akademik, sosyal, kültürel, fiziksel ve ekonomik yönden farklılıklarına dikkat ederek bireylerin eğitim alma hakkına önem verdiği için öğrenci merkezlidir (Sakız \& Apak, 2019).

Program öğrencinin eksiklerini belirleyerek onları en iyi şekilde gidermeyi amaçlamaktadır. Öğrenciye çalışmalarla gerekli yönlendirmeler yapılır. Öğrencinin öğrenmeyi öğrenmesi beklenir. Bununla, sorun çözme kabiliyetini kazanması hedeflenir. Öğrencinin kendi kendini yönetmesi ve iş birliğine dayalı bir öğretimi tercih etmesi beklenir. Akranlarıyla çalışma grupları oluşturup, ortak değerlendirme çalışmaları yaparlar. Öğrenci merkezli olan program öğrencinin ilgi ve isteklerine göre hazırlanmıştır. Öğrenci böylelikle derse katılması için daha istekli olması beklenir.

\section{Dört Dil Becerisine Uyumluluk}

Kapsayıcı eğitim, bireylerin fiziksel olarak dezavantajlı olduğu görsel, işitsel, dilsel gibi sağlık sorunlarının, eğitim alma hakkına engel olmaması gerektiğini savunur (Sakız, 2016). Bu nedenle 
kapsayıcı İngilizce dersi eğitim programı, bireylerin İngilizce eğitimi alırken, fiziksel durumlarının eğitim sürecine olabildiğince az etki etmesini sağlamak için gerekli düzenlemeleri uygulamayı hedeflemektedir. Bu düzenlemeler sınıf içerisinde ve okulda gerekli materyal ve teknolojik altyapının temini, eğitimle iç içe olan bireylerin eğitimiyle, aynı zamanda okul dışında da, toplumsal bilinçlenme ve seminerlerle sağlanabilir (Asar, 2020).

Yabancı dil eğitimi sadece belli bir beceri üzerinden yürümemelidir. Öğrencinin sadece kelime bilgisi ya da sadece dilbilgisi (grammar) bilgisine özgü etkinliklerden kaçınılmalıdır. Dil bir iletişim aracıdır. Öğrenci farklı kültürlerle iletişim kurmak için bütün becerilere sahip olmalıdır. Biriyle konuşurken onu rahat bir şekilde anlaması için dinleme becerisine ihtiyaç duyacaktır. Dinlediği şeye düzgün ve anlaşı1ır bir şekilde cevap vermesi için konuşma becerisine ihtiyacı vardır. Resmi veya özel herhangi bir yazılı eyleminde, göndereceği metni yazmak için yazma becerisi önemlidir. Yine herhangi bir metni okuyup yorumlaması için okuma becerisine ihtiyaç duyar.

Bu program çağdaş toplumun ve eğitimin gereğini yerine getirerek öğrencinin bütün becerilerini geliştirmeyi amaçlamaktadır. Bu becerilerde elde edeceği kazanımlar, öğrencilerin günlük yaşamda kullanabileceği, sosyal iletişimlerde kendini rahat bir şekilde ifade edip cevap verebileceği şekilde düzenlenmiştir.

\section{Kültür ve Değerlere Uyumluluk}

Kapsayıcı eğitim, bireylerin kültürel farklılıklarının ve değerlerinin eğitim alma hakkına engel oluşturmaması gerektiğini savunur. Kültürel farkl1lık ve değerler, bir zenginlik olarak görülüp kültürlerin birbirlerini tanıma firsatı için gerekli sosyal ortam sağlanmalıdır. Bu nedenle arkadaşlık, adalet, sevgi, dürüstlük, saygı, hoşgörü, sorumluluk gibi değerlere önem verilerek bu diyalog ortamı oluşturulmalıdır (Taneri, 2019). Kapsayıcı İngilizce dersi öğretim programı, etnik köken, dil, din, ırk, sosyal statü, ekonomik yetersizlik, fiziksel dezavantaj, cinsiyet ayrımcılığı gibi eğitimine etki etmemesi gereken, kişinin eğitim hakkını engelleyici tüm etkenlerden arındırılarak hazırlanmıştır.

Programın kazanım, etkinlik, tema, ödev ve projeleri de hazırlanırken bu değerlere dikkat edilmiştir. İçerisinde herhangi bir etnik kökeni, kültürü veya topluluğu öne çıkaran veya geri planda tutan uygulama, etkinlik veya cümleler olmamasına dikkat edilerek hazırlanmıştır (Sakız, 2018).

\section{ÖĞRENME-ÖĞRETME SÜRECI}

Kapsayıcı İngilizce dersi eğitim programı, öğrenme-öğretme sürecinde öğrencilerin bireysel farklılıklarına ve akademik seviyelerine dikkat ederek, bireyselleştirilmiş programların hazırlanmasını savunur (Gürgür \& Rakap, 2019). Bu süreçte bireylerin fiziksel olarak dezavantajlı olması eğitim alma hakkına engel teşkil etmeden sınıf içerisinde gerekli materyal temini ve teknolojik imkân sağlanmalıdır. 
Ayrıca bireylerin akademik durumlarına belirlenerek, onları öğrenme-öğretme sürecine etkin katılımı sağlanmalıdır.

$\mathrm{Bu}$ süreçte öğrenci merkezde olmalı ve öğrenci etkin olmalıdır. Öğrencinin etkili olduğu her etkinlik ve kazanım amacına daha kolay ulaşacaktır. Öğrenciyi sürece dâhil etmek ona sorumluluk duygusu da kazandıracağı gibi, öğretmen ve program tarafından konan bu hedefleri kendi hedefleri kabullenip özen gösterecektir (Arslan, 2007). Öğretmen, öğrencinin öğrenme stratejilerini geliştirmesi için de ona rehber olmalıdır (Booth \& Ainscow, 2002). Öğrenci öğrenme stratejilerini geliştirerek, kazanımlara, hedeflere, soruna ya da konuya bakış açısı değişecek, farklı yollarla anlamlandırma sürecine girecektir. Öğrenciye öğrenme stratejileri göstermek, onların derse daha etkin katılımını sağlayacağı gibi, öğrencide öğrenme bilinci oluşturacaktır (Erdem \& Demirel, 2002).

Öğrenciye kazandırılmaya çalıştırılan stratejiler bireysel olması gerektiği gibi grupla öğrenme stratejilerini de içermelidir (Erdem \& Demirel, 2002). Grupla öğrenme stratejilerini öğrenen öğrenci, akranlarıyla sosyal veya akademik daha iyi ilişkiler kuracaktır. İnsan ilişkilerini geliştirmesi öğrencinin kendini daha iyi ifade etmesine ve özgüven kazanmasına faydalı olacaktır (Arslan, 2007). Öğrenme sürecinde daha başarılı sonuçlar almak için işbirlikçi bir anlayış benimsenmelidir. Sürece veli, okul idaresi, konu alan uzmanları da dâhil edilerek onlarında görüşleri alınmalıdır. Öğrenme ortamları öğrencilerin ihtiyaçları doğrultusunda düzenlenmelidir. Sınıfın havadar olması, sınıf tahtası ve panoların düzeni, öğrenci masa ve sıralarının kullanıma elverişli olması, yabancı dil eğitiminin ihtiyaçlarına yönelik olarak teknolojiden olabildiğince faydalanılmalıdır. Görsel ve işitsel ihtiyaçları karşılayacak her türlü materyal sınıfta mevcut olmalıdır.

Konular öğrencinin akademik seviyesine göre seçilmelidir. Öğrenci seviyesine uygun olmayan etkinliklere öğrencinin ilgisi olmayacağı gibi öğrencinin katılımını da olumsuz etkileyecektir (Booth \& Ainscow, 2002). Seçilen konular güncel olmalı, öğrencinin merakını uyandırmalıdır. Güncel olan konular öğrencinin o konuyla ilgili daha fazla bilgiye ulaşmasını ve konuya daha fazla hâkim olabilmek için yapacağı araştırmayı kolaylaştırır. Öğrenme süreci sadece dilbilgisi ve kelime bilgisi üzerinden yürümemelidir. Program dört dil becerisi içermelidir.

\section{YÖNTEM VE TEKNIKK SEÇENEKLERİ}

\section{Yöntem Seçimini Etkileyen Faktörler}

Kapsayıcı İngilizce dersi öğretim programı tüm eğitim sürecinde olduğu gibi yöntem seçiminde de kapsayıcı bir eğitim bakış açısına sahiptir. Öncelikle dersin ve programın amacı her bireyin ulaşabileceği hedeflere uygun olarak seçilmelidir (Sakız \& Apak, 2019). Amaçlar her bireye özgü olarak seçilip, her bireye özgü bir eğitim programı belirlenir. Seçilen konu ve konunun içeriği, öğrencilerin gerçekleştirebileceği ve kavrayabileceği şekilde seçilmelidir. Seçilen konu ve içeriklerde öğrencilerin 
bireysel farklılıkları dikkate alınmalıdır. Seçilen konu ve içeriklere, ayrıca dersin hedeflerine uygun olarak materyallerde öğrenciye ve dersin amacına uygun olarak seçilip uygulanmalıdır. Materyal yapımı ve seçiminde, maliyet, öğrenci sayısı ve zaman dikkate alınmalıdır.

\section{YÖNTEMLER}

Anlatım, tartışma, örnek olay, gösterip yaptırma, problem çözme gibi birçok yöntem, sınıf içerisinde kullanılmaktadır. Kapsayıcı İngilizce dersi öğretim programımızın merkezinde olan bireysel çalışma yöntemi, bireysel farklılıklara önem verdiği için programımızın merkezinde yer almaktadır. Öğrenci merkezli bir yöntemdir. Öğrenci, ilgi ve yetenekleri doğrultusunda konusu kendi belirler. Öğrenci kendi başına, kendi belirlediği yöntemlerle, zamanı kendi belirleyerek yapar (MEB, 2015). Sene başında yapılacak seviye belirleme sınavı bireysel çalışma için oldukça önemlidir. Burada elde edilen veriler öğrencinin ihtiyaçlarını belirlemede oldukça önem teşkil etmektedir. Öğretmen buradan hareketle öğrenciye özgü bireysel bir plan ve çalışma hazırlayabilmektedir. Ayrıca süreç içerisinde, öğrenci isteklerini de eğitime dahil ederek öğrencinin ilgisini çekip, daha istekli bir şekilde derse hazırlanmasını sağlayabilir (Sakız, 2018).

\section{TEKNIKKLER}

\section{Grupla Öğretim Teknikleri}

Kapsayıcı eğitim, bireylerin etnik kökenine, diline, dinine, yani bireyler arasındaki farklılıklara bakmadan, eğitim herkes için bir hak olduğunu vurgular (Booth \& Ainscow, 2002). Buradan aslında sadece öğretmenin değil, öğrencilerin de kapsayıcı eğitim anlayışına sahip olması gerektiği ve birbirlerine değer vermeleri gerektiği göze çarpmaktadır. Bunun öğrenciler arasında, sınıf içerisinde en iyi şekilde oluşmasını sağlamak için kullanılacak grupla çalışma etkinlikleri önem arz etmektedir. Grupla çalışma öğrencilerin birbirlerini daha iyi tanıyıp, birbirlerine daha olumlu bir bakış açısı geliştirmede başarılı olmaktadır (Sakız, 2019).

$\mathrm{Bu}$ tekniklerden biri beyin firtınasıdır. Grup etkinliğiyle yaratıcı düşünmeyi amaçlayan bir tekniktir. Bu tekniğin amacı öğrencilerin bir problemi çözme ile ilgili olarak fikir üretmelerini sağlamak, öğrencileri fikir üretmede etkin kılmak, kendi fikirlerini ifade etmelerini sağlamak ve üretilen fikirlerden yola çıkarak yaratıcı düşünceyi geliştirmektir (MEB, 2015).

Gösteri, rol yapma, drama, benzetim ve diğer eğitsel oyunlar, sınıf içi iletişimi artıran hem görme hem de işitme duyularının etkin olarak kullanıldığı diğer tekniklerdendir. Bu teknikler öğrencilere fiziksel ya da zihinsel beceriler kazandırılırken öğretmen, çalıştırıcı, usta ya da sanatçı kazanımlar ile ilgili işlem basamaklarını araç-gereç, maket, model ya da materyal kullanarak göstermelidir. $\mathrm{Bu}$ etkinlikler için gerekli materyallerin sağlanması önemlidir (Taneri, 2015). 


\section{Bireysel Öğretim Teknikleri}

Öğrenci merkezli bir tekniktir. Kapsayıcı eğitimin amacına ulaşmak için uygulanması gereken tekniklerdendir. Bir sınıfta yavaş ve hızlı öğrenen öğrenciler olabilir. Kapsayıcı İngilizce dersi öğretim programı bireylerin öğrenme farklılığından kaynaklanacak eğitimsel olumsuzların önüne geçmeyi amaçlamaktadır (Sakız, 2019). Öğrencilerin hazırbulunuşluluk seviyeleri de farklı olacaktır. Ayrıca, sınıftaki öğrenci sayısı arttıkça öğrencilere ayrılan süre doğal olarak azalır. Böyle bir sınıfta, bazı öğrenciler hemen, bazı öğrenciler daha geç ve bazı öğrenciler de hiç öğrenememektedir. Tüm bu nedenlerden dolayı Kapsayıcı İngilizce dersi öğretim programı bireyselleştirilmiş eğitimi savunur. Çünkü her öğrencinin kendi seviyesine uygun ve kendine özel olarak hazırlanmış etkinlik ve yöntemlerle öğrencinin başarısı da öğrenme düzeyi de yükselir (Taneri, 2019). Bunu temel alarak öğretmenin de öğretimi mümkün olduğunca bireyselleştirmesi gereklidir. Bunun için sınıfta benzer özelliklere sahip olan 3-5 kişilik küçük homojen gruplar oluşturmalıdır. Bu gruplarda öğrenme, ögrencilerin etkin olduğu bir yapıya sahip olmalıdır. Öğretmenin rolü gruplara rehberlik etmektir.

\section{Sınıf Dışı Öğretim Teknikleri}

Kapsayıcı eğitim, okul ve sınıf içerisinde yapılan çalışmaları, sınıf dışında da uygulayabilmelerini, bireylerin her şart ve duruma hazır olup, bilişsel, duyuşsal ve deyinimsel alandaki davranışlarını geliştirerek, istek ve ihtiyaçlarını belirlemelerini ve karşılayabilecekleri kabiliyete sahip olmalarını öngörür (Oral, 2016).

Sınıf dışarısında uygulanacak tekniklerden bazıları gezi, gözlem, görüşme ve sergi gibi bireylere iç içe olup, hem insan ilişkilerini geliştirme hem de okul ve sınıf içerisinde edindiği bilgileri yaşamla bağlantı kurma şansı bulacağı tekniklerdir. Uygulanacak olan bu teknikler, maddi açıdan öğrencileri zorlayıcı nitelikte olmaması gerekmektedir. Ayrıca uygulanacak etkinliklerin planlanması ve konuyla bağlantılı olması bir diğer önemli noktadır.

Kapsayıcı İngilizce dersi öğretim programında dikkat edilen teknikliklerden diğerleri ise proje ve ödevlerdir. Kapsayıcı İngilizce dersi öğretim programı, bireysel farklılıklara dikkat ederek, her bir öğrenciye dokunacak bireyselleştirilmiş bir programı savunur. Bu nedenle öğrencilere verilecek proje ve ödevler, öğrencilerin ilgi, istek ve ihtiyaçlarını önemseyerek, akademik durumları göz önünde bulundurularak hazırlanmalıdır (Taneri, 2019). Bireyselleştirilmiş olarak verilen ödev ve projeler, öğrencilerin ödevleri eksiksiz aynı zamanda severek yapmasını sağlamaktadır (Arslan, 2007).

\section{ÖLÇME VE DEĞERLENDİRME}

Ölçme ve değerlendirme eğitim-öğretim sürecindeki en önemli öğelerden biridir. Ölçme ve değerlendirme, öğretim programındaki aksaklıkları ve değiştirilmesi gereken uygulamaları tespit etmek ve öğretim programında kullanılan yöntem ve tekniklerden hangisinin ne ölçüde başarılı ve 
uygulanabilir olduğunu görmek için uygulanan süreçlerin bütünüdür (Taneri, 2019). Ölçme ve değerlendirme, öğretim programında belirlenen hedefler, içerik ve kazanımlara uygun olarak belirlenmeli iken amaca yönelik hazırlanmayan ölçme ve değerlendirme araçlarının öğrenme süreçlerine katkıda bulunamayacağı bilinmelidir. Ayrıca bireysel olarak hazırlanmış çalışma ve görevlendirmelerde, bireye özgü bir ölçme ve değerlendirme gerektirir. Kapsayıcı bir eğitim anlayışıyla hazırlanmış bu program, kapsayıcı bir değerlendirmeyi de gerektirir. Eğitimde kapsayıcı ölçme ve değerlendirme, bireysel ihtiyaç ve çeşitliliğin dikkate alınarak, her bir öğrencinin kendi gelişimsel hızı ve potansiyeline göre değerlendirilmesini gerektirmektedir (Sakız, 2019).

\section{İNGILIZCE ÖĞRETIMMINDE KAPSAYICI ÖLÇME DEĞERLENDİRME}

İngilizce öğretimi bir süreçtir. Bu süreçte dil öğretiminde önemli olan becerilerin kazanılması önemlidir. Yabancı dil öğrenmek, okuma, dinleme, konuşma, yazma becerilerini içerir ve bu becerilerin hepsi kendi içerisinde bir bütündür (Yaşar, 2019). İngilizce öğretiminde ölçme ve değerlendirme sadece bu becerileri ölçmez. Aynı zamanda bu becerileri kazanırken, elde edilmiş sosyal ve kültürel özellikleri de ölçer. Ölçmede aynı zamanda bu becerilerin günlük yaşamda ne ölçüde kullanılabildiği de ölçüdür.

Kapsayıcı İngilizce dersi öğretim programı, bireyselleştirilmiş olarak hazırlanan hedef kazanımları, yine bireylerin istek ve ihtiyaçları doğrultusunda, bireysel olarak değerlendirir. Eğitiminde değerlendirme yapmak belirlenen hedeflere ulaşılıp ulaşılmadığını anlamak ve öğrenme sonuçlarını tespit etmek açısından önemlidir (Arslan, 2007). Kapsayıcı İngilizce dersi eğitim programı, öğrenciyi iletişimsel, sosyal, akademik ve programın amaçlarına uygun olarak değerlendirir ve bireylere özgü yeni eğitim programı hazırlamayı amaçlar.

Öğrencilerin istek ve ihtiyaçlarına göre hazırlanan Kapsayıcı İngilizce dersi öğretim programı, bu amaçlarla belirlenen hedefleri tespit etmek için bireyleri ayrı ayrı ve hedefleri de ayrı ayrı değerlendirir (Taneri, 2019). Kapsayıcı eğitimini bireyselleştirişmiş olarak hazırlanmış eğitimin gereği olarak bireyselleştirilmiş değerlendirmeyi kullanır.

\section{Performans Değerlendirme}

İngilizce öğrenmek bir süreçtir ve bu süreç içerisinde öğrenci dil becerilerine maruz kaldığı gibi, sosyal, kültürel birçok iletişim özelliklerini kazanması da beklenir. Bu nedenle öğrencilerin bireysel farklılıklarına göre belirlenmiş olan çalışmalar ve hedefler, yine öğrencilerin bireysel farklılıklarına göre değerlendirilmelidir (Taneri, 2019). Performans değerlendirilmede, öğrencilerin yabanc1 dil öğretiminde hedeflenen becerilerin günlük yaşamda ne kadar kullanabildiklerini ölçtüğü gibi, sorun çözme kabiliyetlerini ne ölçüde kullandıklarını da ölçer. Sorun çözme kullanacağı hem ders kazanımlarından hem de kendi kişisel deneyimlerinden ne ölçüde yararlandığı ölçülmesi hedeflenir (Sakız, 2019). 
Kapsayıcı eğitimin, bireylerin eğitim alma hakkının kutsal olduğu vurgulayarak, bu hakkın devamlılığının sağlanması için, öğrencilerin eğitimden elde ettiği kazanımların sürekli değerlendirilip gözlenmesini savunmaktadır (Sakız, 2015). Bu, süreç içerisinde bireyin performansındaki ve bilgi edinimindeki eksikliği tespit etmek için önemlidir.

\section{Dil Becerilerine Ait Değerlendirme}

Kapsayıcı İngilizce dersi öğretim programı, ders esnasında öğrencilere bilgi aktarımı yaparken, bireylerin fiziksel olarak dezavantajlı olmasına özen göstererek bireyselleştirilmiş olarak eğitim planı hazırlamaktadır. $\mathrm{Bu}$ durum değerlendirme aşamasında da önemlidir. Değerlendirme aşamasında bireysel farklılıklara ve fiziksel olarak dezavantajlı olma durumuna dikkat etmek, bireyselleştirilmiş olarak verilen eğitimin amacına ulaşıp ulaşmadığını en doğru bir şekilde tespit etmek için, bireylere özgü hazırlanan eğitime paralel olarak bir değerlendirme yapmayı gerekli k1lmaktadır (Oral, 2016).

Yabancı dil öğreniminde dört dil becerisi önemlidir. Bu beceriler birbirinden ayrı düşünülemez. Bu becerilerle günlük hayatta karşılaştığı sorunları halledebilir. Sosyalleşerek, karşıdaki kişiyle iletişime geçebilir. Bu nedenle dört dil becerisi bu öğretim programının temelini oluşturur (MEB, 2015). Burada her beceri için uygun ölçme araç ve yöntemlerinin kullanılması çok önemlidir. Amacına uygun olmayan ölçme aracı hedefin başarısı hakkında gerekli bilgiyi bize ulaştıramaz.

Dil becerilerine sahip olmak önemli olduğu gibi, yabancı dili kurallarına uygun olarak konuşmak ve yazmak, doğru bir şekilde anlamak ve okumak için dilbilgisi kurallarını da iyi bilmek gerekir (MEB, 2011). Dilbilgisi kuralları, dil becerilerinden ayrı düşünülmemelidir. Bu nedenle, dilbilgisi kurallarına öğrencinin ne kadar hâkim olduğunu ölçmekte ayrıca önemlidir. Ölçme değerlendirme aşamasında bu dilbilgisi kuralları, dilin doğal kuralları olarak görülüp ölçülmelidir.

Yabancı dilin sesletim becerileri doğru bir şekilde öğrenilip kullanılmalıdır. Konuşmanın akışının bozulmaması ve karşı tarafa iletmek istenilen mesaj doğru bir şekilde aktarılması için bu telaffuz kurallarına dikkat edilmelidir (Yaşar, 2014). Öğrencinin telaffuz becerisinin ölçülmesinde amaç işitme kabiliyetini ve söylev kabiliyetinin ne kadar gelişmiş olduğunun belirlenmesidir.

Öğrenci bütün bu becerilere sahip olsa da kelime bilgisi olmadan yabancı bir dili kullanamayacaktır. Okuduğu, yazdığı, dinlediği her ifadeyi doğru bir şekilde anlaması için ayrıca karşıya mesajını iletmek için konuşurken rahat bir şekilde konuşması için kelime bilgisi çok önemlidir. Kelime bilgisini ölçmek amacıyla eş anlam, zıt anlam, boşluk doldurma gibi aktiviteler kullanılabilir.

\section{Kapsayıcı Değerlendirme}

Bütün değerlendirmelerin, eğitimde eşitliğin ve eğitim alma hakkının herkesin sahip olduğu bir hak olduğu görüşünü unutmadan bireylere özgü yapılan değerlendirmedir. Öğrenciler arasında herhangi bir ayırım gözetmeden, insanı bir değer olarak görüp onu yansız, haksız ve dışlamadan yapılan 
değerlendirmedir (Sakız, 2015). Burada her birey ayrı ayrı değerlendirme dosyaları tutulur. Sonraki dönemde bu değerlendirme dosyaları bir sonraki öğretmene verilir.

\section{KAPSAYICI İNGILIZCCE DERSI ÖLÇME VE DEĞERLENDİRME ARAÇ VE YÖNTEMLERİ}

Kapsayıcı İngilizce dersi öğretim programı, öğrencilerin değerlendirmesi aşamasında, tıpkı programın ana felsefesini oluşturan eşitlikçi ve her birey için eğitim hak olduğu anlayışını değerlendirme aşamasına da yerleştirmiştir. Kapsayıcı değerlendirme anlayışına sahip olmak öğrencilere eşit bir şekilde yaklaşıp onların alma hakkı olduğu eğitimi ulaştırmaktır (Taneri, 2019). Buradaki eşitlik kavramı her ünite için eşit ve her birey için aynı kapsamda değerlendirme olarak algılanmamalıdır. Buradaki eşitlik anlayışı her birey için özenle bir değerlendirme yapmaktır. Kapsayıcı İngilizce dersi eğitim programının her birey için özel olarak hazırlanmasına önem verdiği gibi, her birey için özel, her birey için farklı seviye ve her birey için farklı konularda değerlendirmeyi esas alır (Sakız, 2018).

Buradaki değerlendirme sadece dönem ortası veya sonunda yapılan sinavlar olarak algılanmamalı, değerlendirmenin bir süreç olduğu düşünülüp her an öğrencilerin değerlendirilmesi gerektiği bilinmelidir. Sürekli devam eden değerlendirme, öğrencide yaşanan motivasyon kayb1, isteksizlik, belirli bir konuyu anlayamayıp bir sonraki konuda eksik olduğu hissiyatına kapılma gibi olumsuz durumların önüne set çekecektir. Ayrıca, Kapsayıcı İngilizce dersi öğretim programı, değerlendirmenin demokratik olarak yapılmasını savunur (Gürgür \& Rakap, 2019). Yapılacak olan değerlendirme, öğrenci için anlaşılır ve kabul dilebilir olmalıdır. Yapılacak olan değerlendirmelerde öğrenciyi kendini değerlendirme imkânı da verilmeli öğrenciye kendi eksikleri keşfetme imkânı sunmalıdır. Bu değerlendirmeler bireyleştirilmiş değerlendirme çizgisi taşıyacağı için, her öğrenci için farklılaştırılmış bir değerlendirme olması önemlidir.

Yukarı verilen bilgilerle Kapsayıcı İngilizce dersi öğretim programının değerlendirme yöntemlerinden biri öğretmenin sürekli yapması gereken süreç değerlendirmesidir. Süreç değerlendirmesi, öğretmenin gözlemlerine dayalı bir değerlendirme olduğu için öğretmen tarafindan her an yapılacak bir değerlendirmedir (Gürgür, \& Rakap, 2019). Ayrıca süreç değerlendirmesinde, öğrencinin eğitim-öğretim süresince yaşayacağı herhangi bir her olumsuz durum öğretmen tarafından her an fark edilebilir.

Yine bir diğer değerlendirme çeşidi olarak destekleyici değerlendirmeden söz etmek gerekir. Buradaki destekleyici değerlendirmeyi, öğretmen tarafından yapılan süreç değerlendirmesinin devamı olarak düşünmek gerekir. Destekleyici değerlendirme, öğretmenin süreç değerlendirmesinde yaptığı değerlendirmeyi, öğrenciyi incitmeden ve şevkini kırmadan, öğrenciye yaşadığı eksiklikler veya olumsuz durumlar karşısında nasıl davranması gerektiğini aktarmaktır (Boothm \& Ainscow, 2002). 
Bireyleştirilmiş değerlendirme, Kapsayıcı İngilizce dersi eğitim programının temel ilkelerinden olan bireyleştirilmiş eğitimin olmazsa olmazıdır. Burada öğretmen kendisinden sonraki öğretmenlere de aktaracağı her öğrenci için bireyselleştirilmiş değerlendirme dosyası hazırlar ve her öğrenciyi kendi istek ve ihtiyaçlarına göre, kendi becerileri doğrultusunda değerlendirir (Sakız, 2016). Ayrıca bu dosyaya aslında kapsayıcı bir başka değerlendirme çeşidi olan ve bireyin kendini değerlendirdiği öz değerlendirme bilgileri de bu dosyaya konabilir. Bu değerlendirmelerde hedef, bireyin ve öğretmenin, birey hakkında geçmişte ne düşünüldüğü, şu anki durumu ve gelecekteki potansiyeli anlatılır. $\mathrm{Bu}$ dosyalar bir sonraki öğretmene bırakılarak, bireyin eğitim hayatı boyunca devam edecek bir değerlendirme kaynăğ elde edilmiş olur.

\section{Nitel Değerlendirmeler}

Öğrencilerin kendilerine ne seviyede ifade edebildiklerini anlamak, hitap yeteneği ve hatırlama gücünü görmek, aynı zamanda öğrendikleri bir taslak veya dosya ile sunma yeteneğini geliştirmek amacıyla çeşitli nitel değerlendirme araçlarına ihtiyaç duyulmaktadır (Yaşar, 2014). Bu nitel değerlendirme araçlarından bazıları sözlü sunum, proje, performans ödevleri ve portfolyo olarak sıralamak mümkündür. Bu değerlendirmeler, bireysel kabiliyetlerini arttıracağı gibi grupla içerisinde bir bütün olarak çalışmalar yapma ve değerlendirme kabiliyetini de artmasına olanak sunmaktadır. Hitap ve kendini ifade yeteneğini artırmasının yanı sıra, öğrencilerin birbirleriyle iletişimini artırmasını, aynı zamanda öğrenciye eleştirel düşünme yeteneğini kazandırmasıyla akran değerlendirme de bir diğer nitel değerlendirme araçları arasında görülmektedir (MEB, 2015).

Kapsayıc1 İngilizce dersi öğretim programı, öğrencilerin eksiklerini görerek kendi bireysel programlarını hazırlama olanağı sunmaya ayrı bir yer açmaktadır. Bu nedenle nitel değerlendirmelerden olan öz değerlendirme, kapsayıcı eğitimin üzerinde durduğu bir diğer değerlendirmedir (Taneri, 2019). Öz değerlendirmeyle, öğrenci kendi eksiklerini görerek, eksiklerini, istek ve ihtiyaçları doğrultusunda gidermek için kendi programını hazırlama bilincine ve şansına sahip olmaktadır. Tablo 2'de öğretmen ve öğrenci isteklerine ve öğrencilerin akademik seviyelerindeki farklılıklara göre tekrar şekillenebilecek B1 seviyesinde örnek bir ünite teması hazırlanmıştır 
Tablo 2. Ortaöğretim İngilizce Dersi 10. Sınıf Öğretim Programı (B1 Seviyesi)

\section{Konu 1: GELECEK PLANI}

\section{Kullanılacak Dil}

\section{Dil Beceriler ve Cıktılar}

- Hayallerini söyleme

- Gelecek planlarını anlatma

- İlham aldığı kişilerden bahsetme

What is your future plan?

I want to go to abroad for my education.

\section{- What is your aim in the life?}

I hope to have a job to effect the future of World.

- Who is the most important person for you as an example in future plan?

The most important person is Mandela for me.

\section{- Which job do you want to work?}

I want to work as a doctor.

\section{Dinleme:}

- Öğrenciler önemli insanların başarıları hakkında oluşan diyalogları rahat bir şekilde anlarlar.

- Öğrenciler bir öğrencinin amaçlarını anlattığı diyaloğu anlayabilirler.

\section{Okuma:}

- $\quad$ Öğrenciler kendilerine meslekler hakkında örnek olarak verilen metinleri anlayabilirler.

- Öğrenciler gelecek planları hakkında verilen bir metnin devamını getirebilirler.

Yazma:

- Öğrenciler gelecekteki hayallerini yazabilirler.

- Öğrenciler geleceğin meslekleri başlıklı metin hakkında eleștiri yazabilirler.

\section{Konuşma:}

- Öğrenciler birbirlerine gelecek planları hakkında sorular sorup sohbet edebilirler.

- Öğrenciler gelecekte hayali bir sirket kurup hakkında konuşabilirler.

Not: Öğretmen etkinlik ve ünitelere bașlaman önce ders öncesi, ders esnası ve ders sonrası çalıșmalara uygun olarak, öğrenciyi hazırlamak için ders öncesinde öğrenciyi konuya hazırlamak için ve seviyelerine uygun olarak ödevler verir. Ders esnasında ünite akışıı takip eder. Ders sonrasında da eksik olan noktalarla ilgili tekrar görevlendirme yapar. Ayrıca hazırlanacak olan etkinlik ve üniteler, ders sonrasındaki ödevlendirmeler, akademik olarak farklı seviyedeki öğrenciler düşünülerek düzenlenmesi gerekmektedir.

- Konuşma diyalogları
Materyaller

- Bilgisayar teknolojileri

- Ses ve monitör

- Resimler

- Flash kartlar

- Not alma

- Dinleme dosyaları

- İlgili metinler 


\section{SONUÇ ve ÖNERILER}

Her birey için nitelikli eğitimden faydalanmak temel haklardan bir tanesidir. Bu hakkın, fiziksel olarak dezavantaj, sosyal ve kültürel fark, cinsiyet farklılık, etnik köken, ekonomik durum, çeşitli anlama zorlukları gibi durumlara bakılmadan her birey için sağlanması gerekir (Sakız, 2018). İngilizce dersi kapsayıcı eğitim programı bu hakkı kendine hedef edinerek, bireylerin farklılıklarına veya dezavantajlı olduğu durumlara bakılmadan her bireyin eğitim alma hakkını teslim etmek için hazırlanmıştır.

$\mathrm{Bu}$ çalışma, kapsayıcı eğitimin ilke ve uygulamalarını belirtmek, eğitimin her bireye ulaştırılması sağlamak ve bu alanda yeni bir eğitim programının ihtiyacını gidermek için hazırlanmıştır. Her ne kadar kapsayıc1 eğitimin gereklerini yerine getirmek için yenilikler yapılmış olsa da, programın yeniden gözden geçirilip güncellenmesi gerekmektedir. Kapsayıcı İngilizce dersi öğretim programı bireysel olarak eğitim verildiği gibi, değerlendirmenin de bireysel olması gerektiğini belirtmektedir.

$\mathrm{Bu}$ programda, kapsayıcı eğitimin gereği olarak, ilk harfinden son harfine kadar her bilgi kapsayıcı eğitimin ilkelerine ve amaçlarına göre hazırlanmıştır. Bu nedenle sınıf ortamından ev ortamına, okul ortamından personelin eğitimine, anlatım yöntemlerinden değerlendirmeye, ders içi etkinliklerden kullanılacak materyallere kadar her bir konu bireyin eğitim akma hakkını tesis etmek için hazırlanmıştır.

Bireylerin istek ve ihtiyaçlarına, bireysel farklılıklarına bakmadan hazırlanan bir program her öğrenciyi başarıya ulaştırması düşük bir olasılıktır (Sakız, 2017). Bu nedenle sene başında bireyselleştirilmiş bir değerlendirme yapılması gerektiği vurgulanmıştır. Yapılacak olan değerlendirme sonrası, her birey için özel olarak hazırlanacak bireyselleştirilmiş bir eğitim programının gereği vurgulanmıştır. Öğretmen ve öğrenci sadece belli bir programla sınırlandırılmayıp, öğretmen ve öğrenciye kendi programını yapma imkanı verilmesi gerektiği, bireyin istek ve ihtiyaçlarının karşılanması noktasında ne kadar önemli olduğu belirtilmiştir (Ceyhan, 2016). Ayrıca sınıf içerisinde yapılacak olan etkinlikler de bireyleştirilmiş bir programın gereği olarak bütün öğrencilere hitap etmeli ve bu etkinliklerde kullanılacak olan materyaller her öğrenci düşünülerek hazırlanmalıdır. Daha önce sunulan programlarda bireysel farkl11ıklara ve öğrenci isteklerine hitap etmeden hazırlanan etkinlik, kazanım ve kullanılan materyalleri reddederek, her bireyin kazanılması gerektiği vurgulanmaktadır.

Eğitim herkese eşit bir şekilde sunulması gereken, bireylerin ise ihtiyaç ve özelliklerine uygun bir şekilde yararlanması gereken bir haktır (Booth \& Ainscow, 2002). Bu hak, bireyin ekonomik yetersizliğine, sosyal ve kültürel farklılıklarına, politik düşüncelerine, cinsiyetine, ten rengine, irkına, sağlık olarak sahip olduğu dezavantaja bakılmaksızın, herkesin alması gereken bir haktır. Bu amaçla bu ve bunun gibi hazırlanan tüm programların başarıya ulaşması için birtakım öneriler hazırlanmıştır. 
Topluma, eğitim hakkının herkesin faydalanması gereken bir hak olduğu anlatılmalıdır. Bu hakkın anlatılması toplumunda eğitim hakkının ayrıcalıklı bir gruba veya zümreye değil her bireyin alma hakkı olduğu ve sahip olması gereken bir hak olduğu bilincini kazanmasını sağlayacaktır (Sakız, 2016). Toplum, aslında insanın özünde var olan, duygudaşlık, saygı, sevgi hoşgörülü olma, dürüstlük, özdenetim, vatanseverlik, sorumluluk gibi kök değerler, broşür, afiş, belge, toplantı, panel gibi bilgilendirilme araçlarıyla tekrar hatırlatılıp, öğrencilerimize bu bilinci evlerde de kazandırılmaya çalışmaları gerektiği belirtilmeli, eğitime kendilerinden de destek istenmesinde fayda vardır (Sakız \& Woods, 2015). Toplum, okulla, öğretmenlerle ve öğrencilerin aileleriyle iletişim içinde olmal1, karşılaşılan sorunlara çare üretmeye çalışmaları onlardan da istenmesinde fayda görülmektedir.

Okul idaresi, veli, ögretmenler, öğrenciler, okul personeli ve sivil toplum kuruluşlarıyla bağını koparmamalı, iletişim halinde olup desteklerini sağlaması önemli görülmektedir. Okul altyapısı ve sınıfları kapsayıcı eğitimin sosyal, ekonomik ve kültürel gerekçelerine uygun olarak düzenlemesi gerekmektedir. Okul personeline, öğretmenlere ve öğrencilere eğitim hakkı, karşılıklı sevgi ve sayg1 temelli, kapsayıcı eğitimin temellerini oluşturan kazanımları, çeşitli bilgilendirme araçlarıyla, seminerlerle ve platformlarla aktarılması için gerekli bilgilendirme yapılmalıdır. Okul idaresi de bu amaçla gerekli eğitim seminerlerini almasında fayda vardır.

Okul ve sınıflar, çağımızın gereklerine, ayrıca eğitimin herkese eşit bir şekilde ulaşmasını sağlayacak gerekli teknolojik altyapıya sahip olacak şekilde donatılması ifade edilebilir (Sakız, Woods, Sart, Erşahin, Aftab, Koç \& Sarıçam, 2015). Okul ve sınıflar, öğretmenlerin, öğrencilerin, velilerin ve personelin birbirleriyle ve okul idaresiyle etkileşimini ve diyaloğunu artıracak şekilde dizayn edilmesi bir diğer ihtiyaç olarak göze çarpmaktadır.

Okul personellerinin de bu süreçte üzerine düşen görevleri olacaktır. Personel, kapsayıcı okul kültürlerine uyumlu ilke, tutum ve inançların yer aldığı okul kültürlerine uyum sağlayacak özelliklere sahip olmalıdır (Asar, 2020). Personel öğrenci, öğretmen, veli ve okul yönetimiyle iyi ve olumlu ilişki kurmal1, toplumun sevgi ve saygı çerçevesinde kök değerlerini bilen ve uygulayan özelliklere sahip olmalıdır. Personel, kapsayıcı ilke ve uygulamalara yönelik farkındalık ve beceri gelişimini sağlayacak gerekli seminer ve eğitimleri alması önemli görülmektedir.

Öğretmenler, eğitimden her bireyin eşit bir şekilde yararlanmasını sağlamak için, sınıfa bütünlük ve aidiyet duygusunu kazandırmalıdır. Bunu öncelikle öğrencilere eşit bir şekilde yaklaşarak, sınıf disiplinini herkesin kabul ettiği kararlarla sağlamalı, her bireye eşit sorumluluklar verilebilir (Cole, 2008). Öğretmenler, kapsayıcı eğitimin gereklerini yerine getirecek gerekli eğitim ve seminerleri almalıdır. Öğretmenler veli, öğrenci, okul idaresi ve okul personeliyle iletişime geçip, öğrencilerim eğitimi için gerekli önlemlerin alınıp, maddi-manevi desteklerin karşılanmasını sağlamak ayrıca önem teşkil etmektedir. Öğretmen öğrencilerin ihtiyaçları ve isteklerini bilmeli, onları tanımalı, onlara dokunmayı başarması kapsayıcı eğitimin gereği olarak söylenebilir.. 
MEB öncelikle yukarıda belirtilen gereksinimlerin karşılanması için, gerekli altyapı, materyal ve teknolojik gereksinimleri karşılama konusunda sürekli güncellenen ve değişen eğitimsel ihtiyaç ve durumları dikkate alarak gerekli düzenlemeleri sürekli yapmasında fayda görülmektedir (Ceyhan, 2016). MEB, okulların kapsayıcı eğitimin sosyal ve eğitimsel gerekçelerine uygun olarak inşa edilip, dizayn edilmesini sağlamalıdır. MEB, okul idaresi, öğretmen ve okul personelinin eğitimde kapsayıcılığı karşılamaları için öncelikle üniversitelerde, daha sonra da okullarda gerekli eğitim ve seminer verilmesini sağlamak bir diğer önemli başlık olarak görülmektedir (Sakız, 2018). Kitaplar, müfredat ve materyaller, eğitimin herkese ulaşabilmesi doğrultusunda hazırlanmalı, her bireyin ihtiyaçları ve seviyesine uygun olarak eğitimin bir hak olduğu anlayışı doğrultusunda tekrar oluşturulması kapsayıcı eğitimin gereği olarak söylenebilir (Taner, 2019). MEB, çağın gelişmelerini takibi için sürekli yenilenmeye açık ve hazır olması önem arz etmektedir. Teknolojinin etkin kullanımı için okullarda verilen eğitimin pekiştirilmesine yardımcı yardımcı olmak amacıyla Eğitim Bilişim Ağı(EBA) gibi platformların içerik ve altyapıları geliştirilmeli, buna benzer uygulama ve sitelerin kurulması sağlanmalıdır.

\section{Ek Beyan}

Yazar katkı oranları: 1. yazar \%60 oranında, 2. yazar \%40 oranında katkı sağlamıştır.

Araştırma ve yayın etiği ilkelerine uygun hareket edildiğine dair metin: Makalenin tüm süreçlerinde JCRE'ın araştırma ve yayın etiği ilkelerine uygun olarak hareket edilmiştir.

Çıkar çatışması bildirimi: $\mathrm{Bu}$ çalışmada herhangi bir potansiyel çıkar çatışması bulunmamaktadir. 


\section{KAYNAKÇA}

Arslan, M. (2007). Constructivist approaches in education. Ankara University Journal of Faculty of Educational Sciences, 40(1), 41-61

Asar, M. (2020). Kapsayıcı öğrenme ortamlarına ilişsin yöneticilerin görüşleri (Denizli ili Pamukkale ilçe örneği).

Booth, T., \& Ainscow, M. (2002). Index for inclusion: Developing learning and participation in schools. Bristol: Center for Studies on Inclusive Education

Ayan-Ceyhan, M. (2016). Kapsayıcı eğitim: okul pratikleri, öğretmen ihtiyaçları Eğitimde Reform Girişimi. İmak Ofset Basım yayım. İstanbul

Cole, R. W. (2008). Educating everybody's children : diverse teaching strategies for diverse learners (2nd ed.). Alexandria, Virginia: Association for Supervision and Curriculum Development

Demirezen, M. (2003). Yabanci dil ve anadil öğreniminde kritik dönemler. TÖMER Dil Dergisi, 118, 5-15

Düşkün, Y. (2016). Türkiye'de ortä̈ğretimde kapsayıcı eğitim durum analizi. Haziran

Erdem, E., \& Demirel, Ö. (2002). Constructivism in curriculum development. Hacettepe Üniversitesi Ĕgitim Fakültesi Dergisi, 23, 81-87

Gürgür, H., \& Rakap, S. (2019). Kapsayıcı eğitim: Özel eğitimde bütünleştirme. Ankara: Pegem

Kuyucu, M. (2017). Y Kuşağı ve Teknoloji: Y Kuşağının İletişim Teknolojilerini Kullanım Alışkanlıkları. Gümüşhane Üniversitesi İletişim Fakültesi Elektronik Dergisi, 5(2), 845-872.

MEB, (2011). Ortaöğretim Kurumları İngilizce Dersi Öğretim Programı. Ankara

MEB, (2015). Ortaöğretim Kurumları İngilizce Dersi Öğretim Programı. Ankara

Oral, I. (2016). Türkiye'de Kapsayıcı Eğitimi Yaygınlaştırmak İçin Politika Önerileri. İmak Ofset Basım yayım. Istanbul

Sakız, H., Woods, C., Sart, H., Erşahin, Z., Aftab, R., Koç, N., \& Sarıçam, H. (2015). The route to 'inclusive counselling': Counsellors' perceptions of disability inclusion in Turkey. International Journal of Inclusive Education, 19(3), 250-269.

Sakı, H., \& Woods, C. (2015). Achieving inclusion of students with disabilities in Turkey: Current challenges and future prospects. International Journal of Inclusive Education, 19(1), 21-35.

Sakı, H. (2016). Göçmen çocuklar ve okul kültürleri: Bir bütünleştirme önerisi. Göç Dergisi, $\quad$ 3(1), 6581.

Sakiz, H. (2016). Thinking Change Inclusively: Views of Educational Administrators on Inclusive Education as a Reform Initiative. Journal of Education and Training Studies, 4(5), 64-75.

Sakiz, H. (2017). İmpact of an inclusive programme on achievement, attendance and perceptions towards the school climate and social-emotional adaptation among students with disabilities. Educational Psychology, 37(5), 611-631.

Sakiz, H. (2018). Students learning disabilities within the context of inclusive education: issues of identification and school management. International Journal of Inclusive Education, 22(3), 285-305. 
Sakız H., Sarıcalı M. (2018). Including students with visual difficulty within higher education: necessary steps. Exceptionality, 26(4), 266-282.

Sakız, H., \& Apak, H. (2019). Türkiye'de göçmen kapsayıcllı̆̆ı: Sorundan firsata dönüşüm önerileri. Ankara: Pegem

Sakız, H. (2019). Göçmen eğitiminde psikolojik unsurlar. İçinde Sakı, H. \& Apak, H. (Ed.). Türkiye'de göçmen kapsayıcıllğg: Sorundan firsata dönüşüm önerileri (s. 187-207). Ankara: Pegem.

Taneri, P. O. (Ed.) (2019). Kuramdan uygulamaya kapsayıcı eğitim. Ankara: Pegem

Yaşar, M. (2014). Öğretmen adaylarının "eğitimde ölçme ve değerlendirme" dersine yönelik tutumlarının bazı değişkenler açısından incelenmesi. Trakya Üniversitesi Eğitim Fakültesi Dergisi, 4(2), 64-83. 